NASA/TM-2009-215594

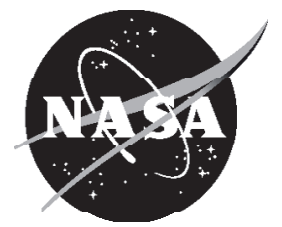

\title{
FJ44 Turbofan Engine Test at NASA Glenn Research Center's Aero-Acoustic Propulsion Laboratory
}

Joel T. Lauer, Joseph McAllister, and Raymond A. Loew Sierra Lobo, Inc., Cleveland, Ohio

Daniel L. Sutliff

Glenn Research Center, Cleveland, Ohio

Thomas C. Harley

Williams International, Walled Lake, Michigan 


\section{NASA STI Program . . . in Profile}

Since its founding, NASA has been dedicated to the advancement of aeronautics and space science. The NASA Scientific and Technical Information (STI) program plays a key part in helping NASA maintain this important role.

The NASA STI Program operates under the auspices of the Agency Chief Information Officer. It collects, organizes, provides for archiving, and disseminates NASA's STI. The NASA STI program provides access to the NASA Aeronautics and Space Database and its public interface, the NASA Technical Reports Server, thus providing one of the largest collections of aeronautical and space science STI in the world. Results are published in both non-NASA channels and by NASA in the NASA STI Report Series, which includes the following report types:

- TECHNICAL PUBLICATION. Reports of completed research or a major significant phase of research that present the results of NASA programs and include extensive data or theoretical analysis. Includes compilations of significant scientific and technical data and information deemed to be of continuing reference value. NASA counterpart of peer-reviewed formal professional papers but has less stringent limitations on manuscript length and extent of graphic presentations.

- TECHNICAL MEMORANDUM. Scientific and technical findings that are preliminary or of specialized interest, e.g., quick release reports, working papers, and bibliographies that contain minimal annotation. Does not contain extensive analysis.

- CONTRACTOR REPORT. Scientific and technical findings by NASA-sponsored contractors and grantees.

- CONFERENCE PUBLICATION. Collected papers from scientific and technical conferences, symposia, seminars, or other meetings sponsored or cosponsored by NASA.

- SPECIAL PUBLICATION. Scientific, technical, or historical information from NASA programs, projects, and missions, often concerned with subjects having substantial public interest.

- TECHNICAL TRANSLATION. Englishlanguage translations of foreign scientific and technical material pertinent to NASA's mission.

Specialized services also include creating custom thesauri, building customized databases, organizing and publishing research results.

For more information about the NASA STI program, see the following:

- Access the NASA STI program home page at http://www.sti.nasa.gov

- E-mail your question via the Internet to help@ sti.nasa.gov

- Fax your question to the NASA STI Help Desk at 301-621-0134

- Telephone the NASA STI Help Desk at 301-621-0390

- Write to: NASA Center for AeroSpace Information (CASI) 7115 Standard Drive Hanover, MD 21076-1320 
NASA/TM-2009-215594

AIAA-2009-0620

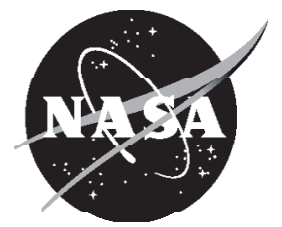

\section{FJ44 Turbofan Engine Test at NASA Glenn Research Center's Aero-Acoustic Propulsion Laboratory}

Joel T. Lauer, Joseph McAllister, and Raymond A. Loew

Sierra Lobo, Inc., Cleveland, Ohio

Daniel L. Sutliff

Glenn Research Center, Cleveland, Ohio

Thomas C. Harley

Williams International, Walled Lake, Michigan

Prepared for the

47th Aerospace Sciences Meeting

sponsored by the American Institute of Aeronautics and Astronautics

Orlando, Florida, January 5-8, 2009

National Aeronautics and

Space Administration

Glenn Research Center

Cleveland, Ohio 44135 


\section{Acknowledgments}

The authors would like to acknowledge the dedicated efforts of the support crew in the AAPL facility; especially Mark Jacko, Lenny Smith, Ed Mysliwiec, Bruce Groene, Gary Novotnak, Vic DeCapite, and Bill Magas. Dr. Cheryl Bowman of the NASA Glenn Research Center's Advanced Metallics Branch provided critical fabrication and operational assistance. Dr. Mohan Hebsur, formerly of Ohio Aerospace Institute, provided the foundational work on foam metal liners. The Williams International team members: Dean Musgrave, Jim Dorer, Dennis Sochocki, Dan Schester, Chris Nona, Glenn Guenther, Ryan Ellis, Big Doug Meenderink, Brian McCaffrey, Bernie Bobola, Bill Rayburn, Sean Harding, and Dave Prescott put forth their best ideas, time, and efforts and proved once again that it takes a total team effort to achieve success.

Trade names and trademarks are used in this report for identification only. Their usage does not constitute an official endorsement, either expressed or implied, by the National Aeronautics and Space Administration.

This work was sponsored by the Fundamental Aeronautics Program at the NASA Glenn Research Center.

Level of Review: This material has been technically reviewed by technical management.

Available from

NASA Center for Aerospace Information 7115 Standard Drive

Hanover, MD 21076-1320
National Technical Information Service 5285 Port Royal Road Springfield, VA 22161 


\title{
FJ44 Turbofan Engine Test at NASA Glenn Research Center's Aero-Acoustic Propulsion Laboratory
}

\author{
Joel T. Lauer, Joseph McAllister, and Raymond A. Loew \\ Sierra Lobo, Inc. \\ Cleveland, Ohio 44135 \\ Daniel L. Sutliff \\ National Aeronautics and Space Administration \\ Glenn Research Center \\ Cleveland, Ohio 44135 \\ Thomas C. Hartley \\ Williams International \\ Walled Lake, Michigan 48390
}

\begin{abstract}
A Williams International FJ44-3A 3000-lb thrust class turbofan engine was tested in the NASA Glenn Research Center's Aero-Acoustic Propulsion Laboratory. This report presents the test set-up and documents the test conditions. Farfield directivity, in-duct unsteady pressures, duct mode data, and phased-array data were taken and are reported separately.
\end{abstract}

\section{Introduction}

Significant reduction in aircraft noise is required to meet continually stricter noise regulations in the USA and Europe. Since the turbofan engine is a large contributor to aircraft noise, any overall reduction in aircraft noise must address engine noise reduction (Ref. 1). NASA's Subsonic Fixed Wing project under the Fundamental Aeronautics program emphasizes developing technologies for reducing noise for subsonic aircraft. The engine test herein was initiated under the Innovative Partnerships Program that enables cost-shared projects to address barriers and remove obstacles to technology development. These efforts could lead to larger development partnerships and projects that would be of greater significance and value to NASA.

Acoustic liners in current aircraft engines are generally located in the inlet section upstream of the fan. If the liner could be placed nearer to the fan rotor, or over the rotor, significant additional noise attenuation could be realized. Typically, acoustic liners have not been implemented over the rotor due to aerodynamic and structural considerations as well as the inability of liners to withstand tip rubs. These issues could be resolved if a liner were made of metallic foam with suitable acoustic properties.

A proto-type Foam Metal Liner (FML) was successfully developed and tested (Ref. 2) on a NASA Glenn Research Center (GRC) low-speed concept fan test rig. This test demonstrated the potential of metal foam liners for reducing fan noise. Bench top lab tests indicated that the metal foam liner could withstand expected engine environments. What was undetermined was the acoustic performance of foam metal liners in a high-speed, high-pressure ratio engine environment and the impact of the FML on the aerodynamic performance of the engine.

\section{Facility and Test Article Overviews}

The Williams International FJ44-3A engine was tested in the Aero-Acoustic Propulsion Laboratory (Ref. 3) (AAPL) located at the NASA Glenn Research Center. Several inlet liner configurations were tested for acoustic limited performance efficacy compared to the baseline hardwall. Two FMLs were 
designed, fabricated, and evaluated. Two Single Degree of Freedom liners were designed and fabricated using current methodologies and also evaluated to provide a state-of-the art comparison for the FMLs.

\section{Aero-Acoustic Propulsion Laboratory (AAPL)}

The Aero-Acoustic Propulsion Laboratory (AAPL) dome is 65 - $\mathrm{ft}$ high and $130-\mathrm{ft}$ in diameter, providing an anechoic testing environment for engine component research and development (Fig. 1). To provide an anechoic environment, custom-designed 2-ft thick fiberglass wedges are mounted on the dome's interior walls and floor areas adjacent to the test rigs. These wedges provide an anechoic environment down to $125 \mathrm{~Hz}$.

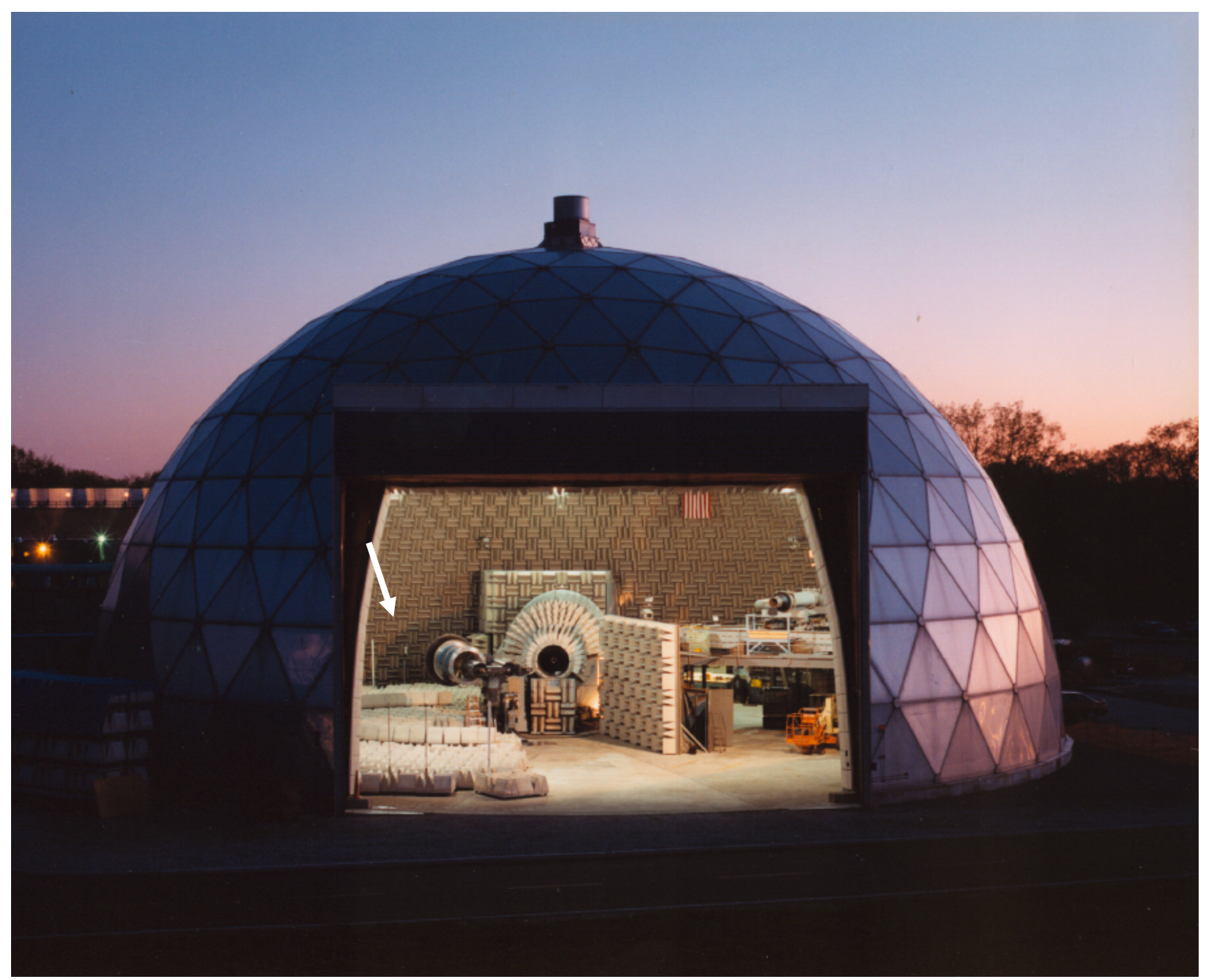

Figure 1.-Aero-Acoustic Propulsion Laboratory (AAPL).

The FJ44 could not be placed in the center of the AAPL due to constraints from existing test rigs. The inlet plane was placed $\mathrm{X}=-18 \mathrm{ft} 4 \mathrm{in}$. and $\mathrm{Y}=18 \mathrm{ft} 6 \mathrm{in}$. from the center of the dome. The approximate installation location can be seen in Figure $1-\mathrm{a}$ fan rig that was tested much earlier can be seen just to the left of the center in approximately the same location where the FJ44 was located. The engine centerline was $10 \mathrm{ft}$ above the floor. Figure 2 shows the engine in the AAPL facility. Figure 3 shows a close-up of the engine fully installed and instrumented. Note that the door behind the engine remains open when testing. 


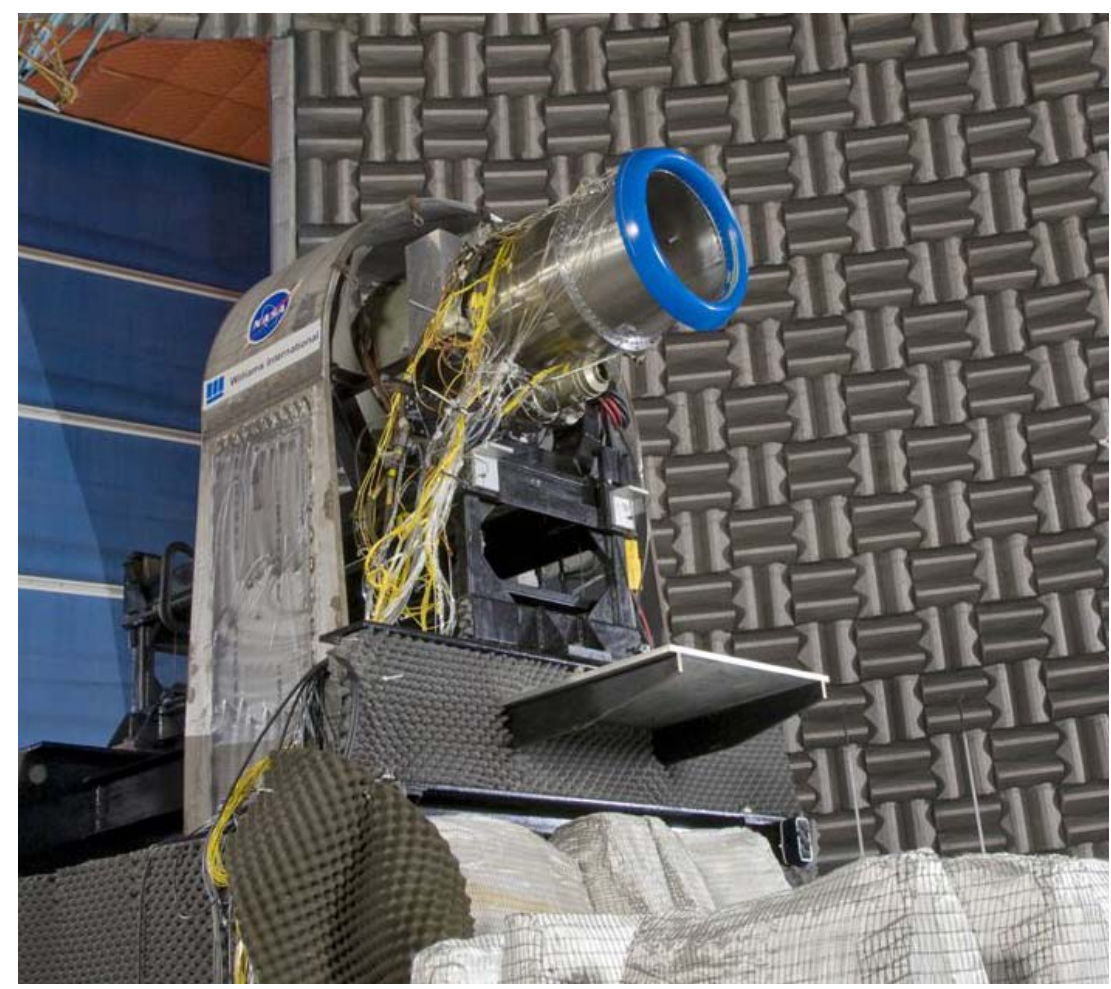

Figure 2.-Engine located in AAPL.

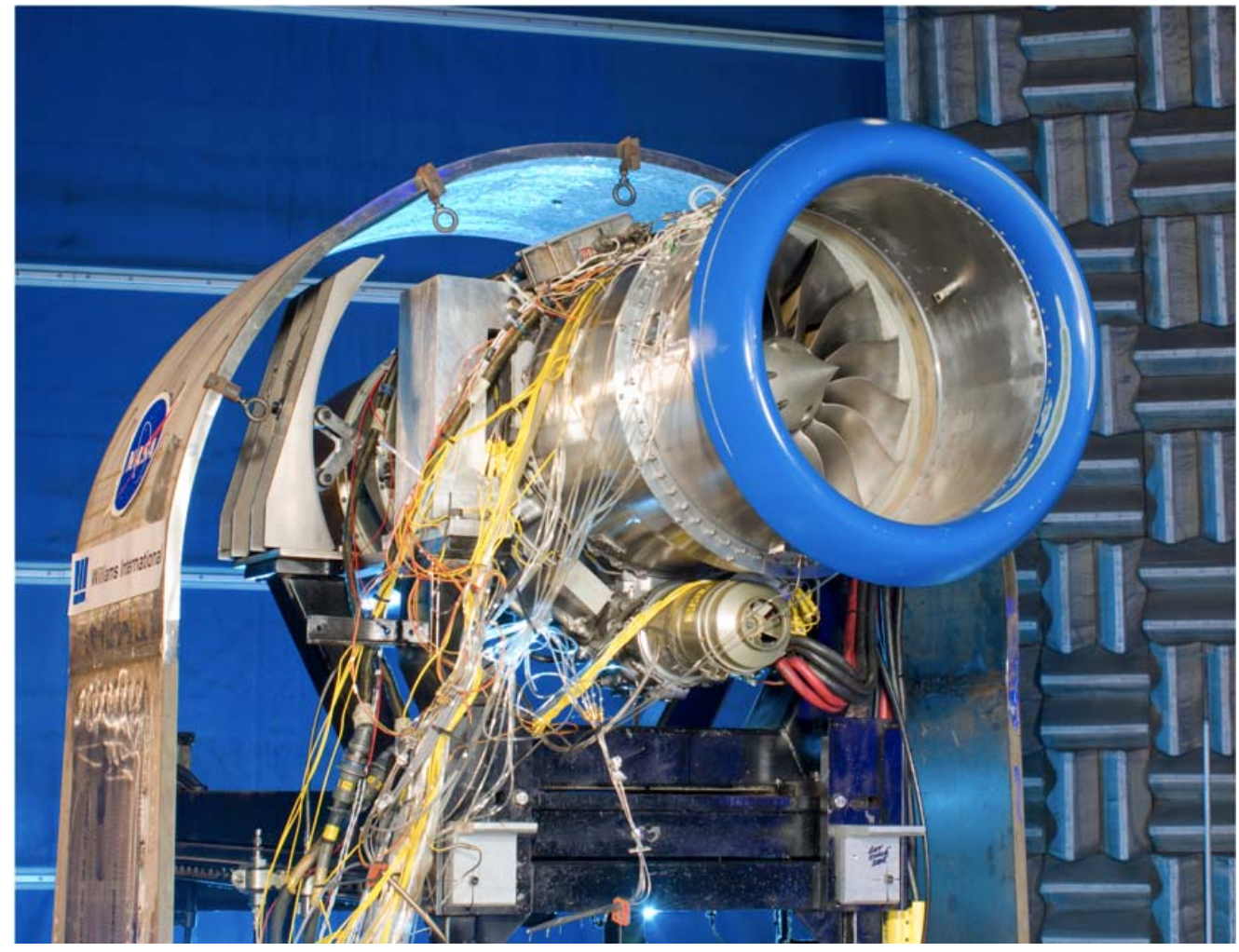

Figure 3.-Close-up of engine located in AAPL. 
TABLE I.-FJ44-3A CHARACTERISTIC ENGINE PARAMETERS

\begin{tabular}{|l|c|}
\hline Base engine weight & $525 \mathrm{lb}$ \\
\hline Base engine length & $48 \mathrm{in}$. \\
\hline Base engine diameter & $23 \mathrm{in}$. \\
\hline Thrust class & $3,000 \mathrm{lbf}$ \\
\hline
\end{tabular}

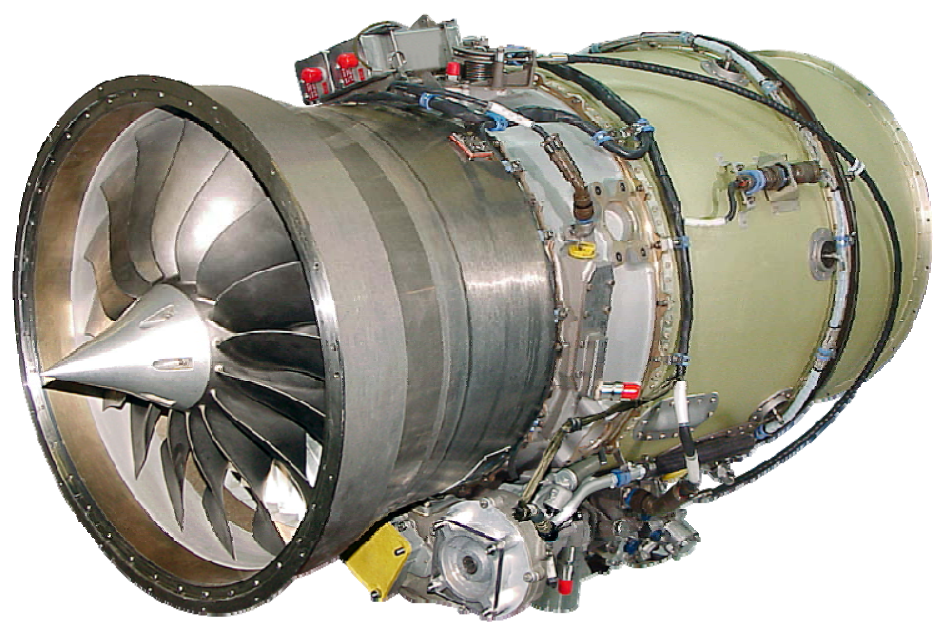

Figure 4.-Williams International FJ44-3A.

\section{FJ44-3A Turbofan Engine Description}

The FJ44-3A engine is a dual-spool low-bypass ratio turbofan engine that was certified in 2004 for FAR 23 and FAR 25 airplanes (Federal Aviation Regulations). The low-pressure spool of the engine comprises an integrally bladed wide chord fan and blisk compressor stages driven by a two-stage low-pressure turbine. The high-pressure spool of the engine comprises a single stage centrifugal compressor driven by a single stage high-pressure turbine. The combustor is an effusion-cooled annular design. The exhaust system is typically a long duct with an internal daisy-lobe mixer. The inlet system is typically a pitot design. Basic information of the FJ44-3A engine is provided in Table I, and the engine is shown in Figure 4.

\section{Engine control}

Control of the engine was provided by a Full Authority Digital Engine Control (FADEC) system. Various rig sensors were interfaced to the facility emergency shutdown (ES) control string, to initiate an automatic engine shutdown in the event of an equipment failure or parameter excursion beyond set point limits. An automatic facility ES would occur with pre-defined excess fan or turbine shaft speeds, or high inter-stage turbine temperature, or a FADEC failure. A pushbutton located in the AAPL control room was provided for personnel to manually initiate an ES as well. In the event of an ES, the fuel to the engine would have been cut off resulting in the engine coasting down to zero rpm. Engine accelerometers and other sensors were interfaced with the facility's programmable logic controller and displayed on the graphical operator interface for manual monitoring.

\section{Support Hardware}

\section{Engine Stand/Structure}

The engine stand consisted of a lower riser stand, mid riser stand, thrust stand, engine cradle, containment shield, and an Inlet Control Device (ICD) mobile stand. Figure 5 shows a schematic of the integrated test stand. Williams International supplied the lower riser stand, mid riser stand, thrust stand, and engine cradle. The FJ44-3A engine was installed in AAPL at a centerline height of $10 \mathrm{ft}$. Ten feet is an acoustical standard at AAPL and has been used for all of its acoustic testing. To meet this height requirement, the lower riser stand had to be designed and fabricated. Williams International completed the design work with assistance from ASRC and NASA on mounting requirements (Ref. 4). The containment shield was designed by NASA and ASRC, and fabricated by Williams International. The engine stand along with all additional hardware was mounted to AAPL's concrete floor. 


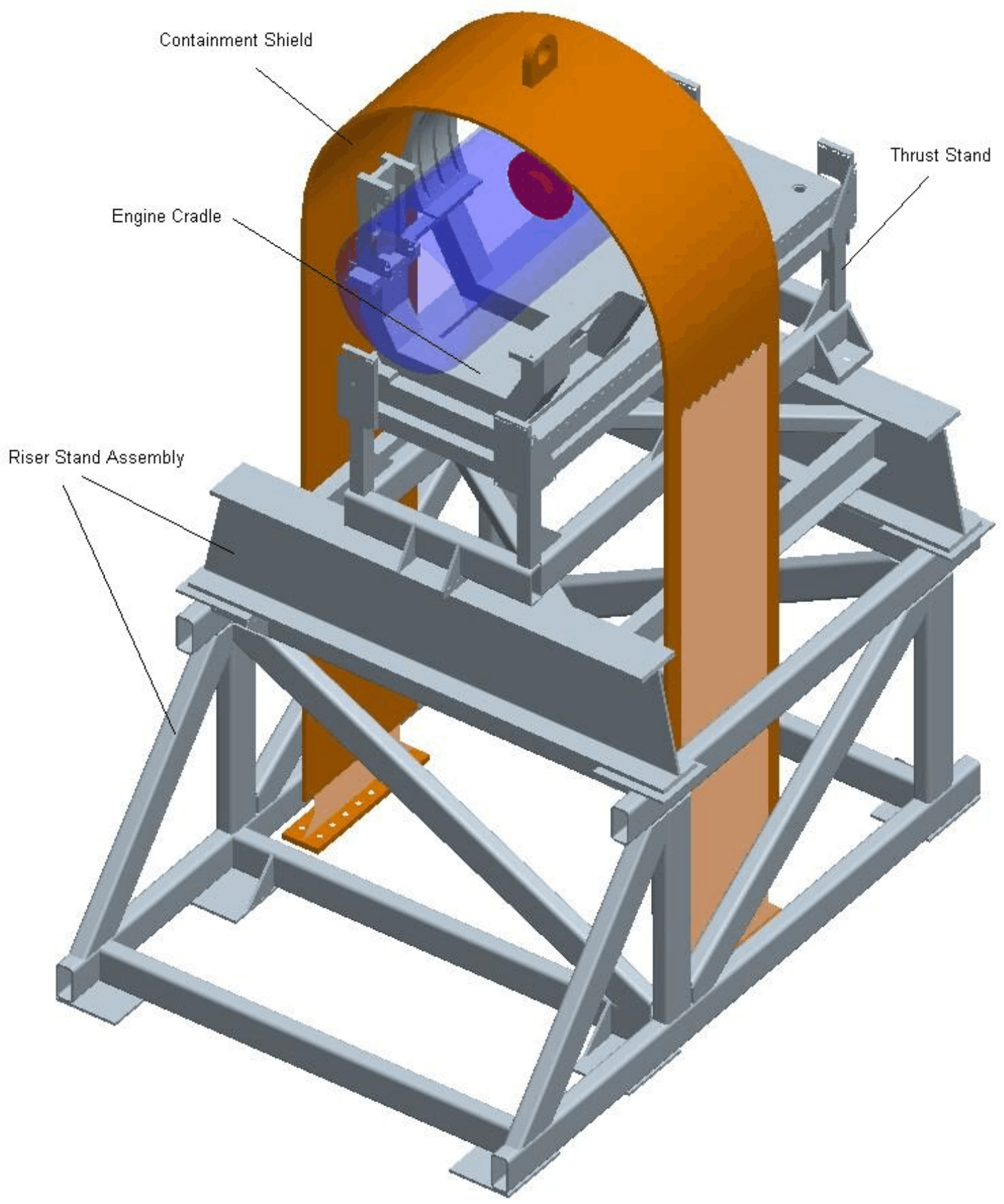

Figure 5.-Schematic test stand and containment shield. 


\section{Containment}

A containment shield was integrated into the test setup as dictated by NASA safety requirements for onsite live engine testing. The containment shield is a safety requirement of high-speed engine testing at NASA. The containment shield needed to be designed to contain a tri-hub failure of the engine turbine. The design was subject to the following specific requirements

Penetration.- Shield thickness should be designed to contain energy of tri-hub failure of the turbine rotor hub.

Retention.-Assumed half the total kinetic energy of rotor failure is directed in any one particular direction (i.e., can anticipate a 10-piece failure with even angular distribution of part trajectories).

Width.-Design shield to cover the turbine section of the engine (High Pressure Turbine (HPT) and Low Pressure Turbine (LPT)).

Speeds.-For computing kinetic energy upon failure, use design guide 120 percent over-speed criteria in conjunction with 100 percent rotational speeds specified by Williams International for FJ44-3 engine.

Damage Containment Criteria.- Objective is to contain damage to interior of AAPL facility in event of a failure. It is acceptable for the containment shield to tear out of the floor and travel a short distance provided all fragments and containment hardware are contained within the AAPL facility. In such instance, acoustic wedge damage and some interior facility damage would be considered acceptable. Momentum transfer and inertia should not be discounted as factors in dissipating projectile kinetic energy.

Configuration.- - It is desirable to keep the shield close to the engine for acoustic, size, and fragment capture considerations. Ricochet plates are not required/desired (deemed unnecessary during previous FJ44 tests at NASA's PSL facility and detrimental to acoustics). A scatter angle of $15^{\circ}$ is acceptable.

\section{Fuel System}

The fuel system implemented was similar to those used in the Williams International test cells. The tank was a 500-gal double-walled, skid-mounted tank located outside the AAPL facility. The tank met requirements for UL142, as well as meeting environmental regulations for spill containment. The tank had an over pressurization relief valve as well as a level monitor and interstitial space level inspection capabilities. Electrical grounding was also required and installed according to National Electrical Code, NFPA 70.

Fuel line pressure and temperature were monitored and incorporated HI and LOW level alarms. A pressure relief valve was installed downstream of the supply pump provided protection in the event of over-pressure. The fuel system was plumbed with stainless steel tubing and 3/4-in. Swagelok type connections. Two emergency actuated shutoff valves were integral to the system. One was located at the fuel pump near the tank and the other was installed close to the engine. Both valves were setup to fail closed with a 0.5 -sec close time. The valves were one of the emergency shutdowns paralleled into the AAPL control string. All fuel system components other than the last emergency shutoff valve near the engine were mounted on a panel located outside of the AAPL facility near the fuel tank.

\section{Flow Conditioning}

The ICD used for the inlet flow conditioning was borrowed from the AAPL's Advanced Noise Control Fan concept test rig. Figure 6 shows the ICD from two views. The ICD was mounted on the mobile stand to be able to readily move it away from the inlet of the FJ44 to perform model changes. Figure 7 shows a photo of the ICD with the containment shield offset. 


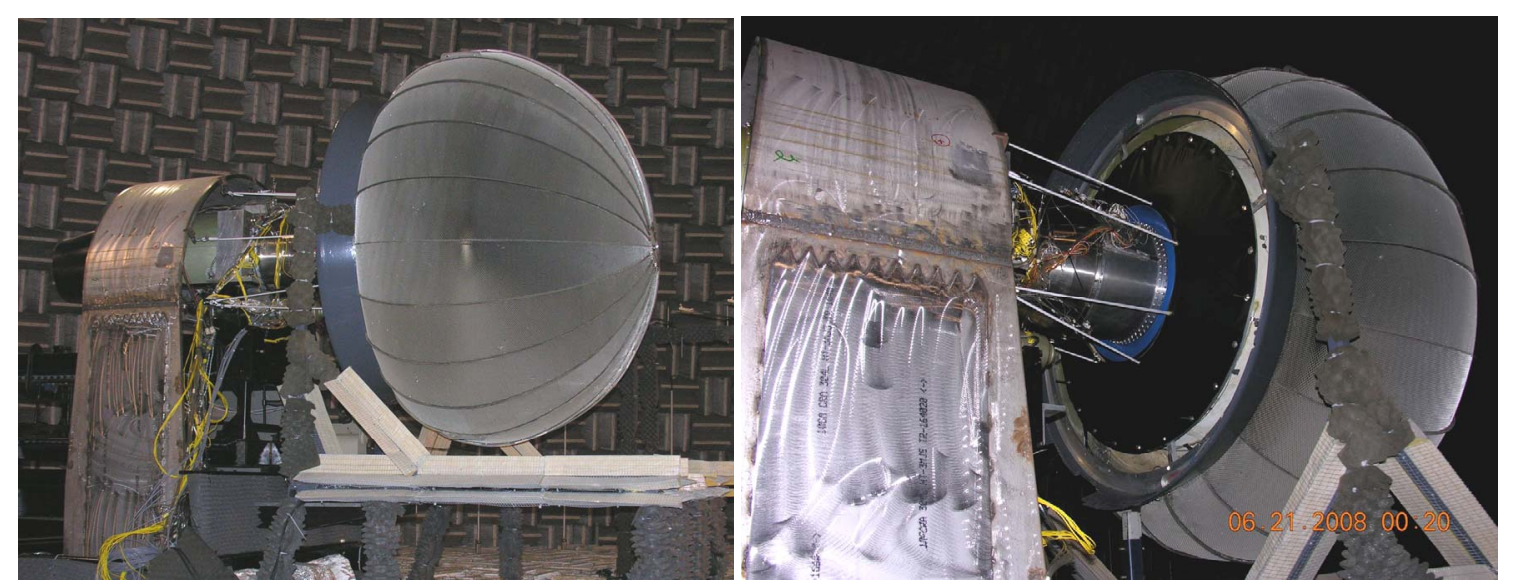

Figure 6.-Test stand with ICD mounted.

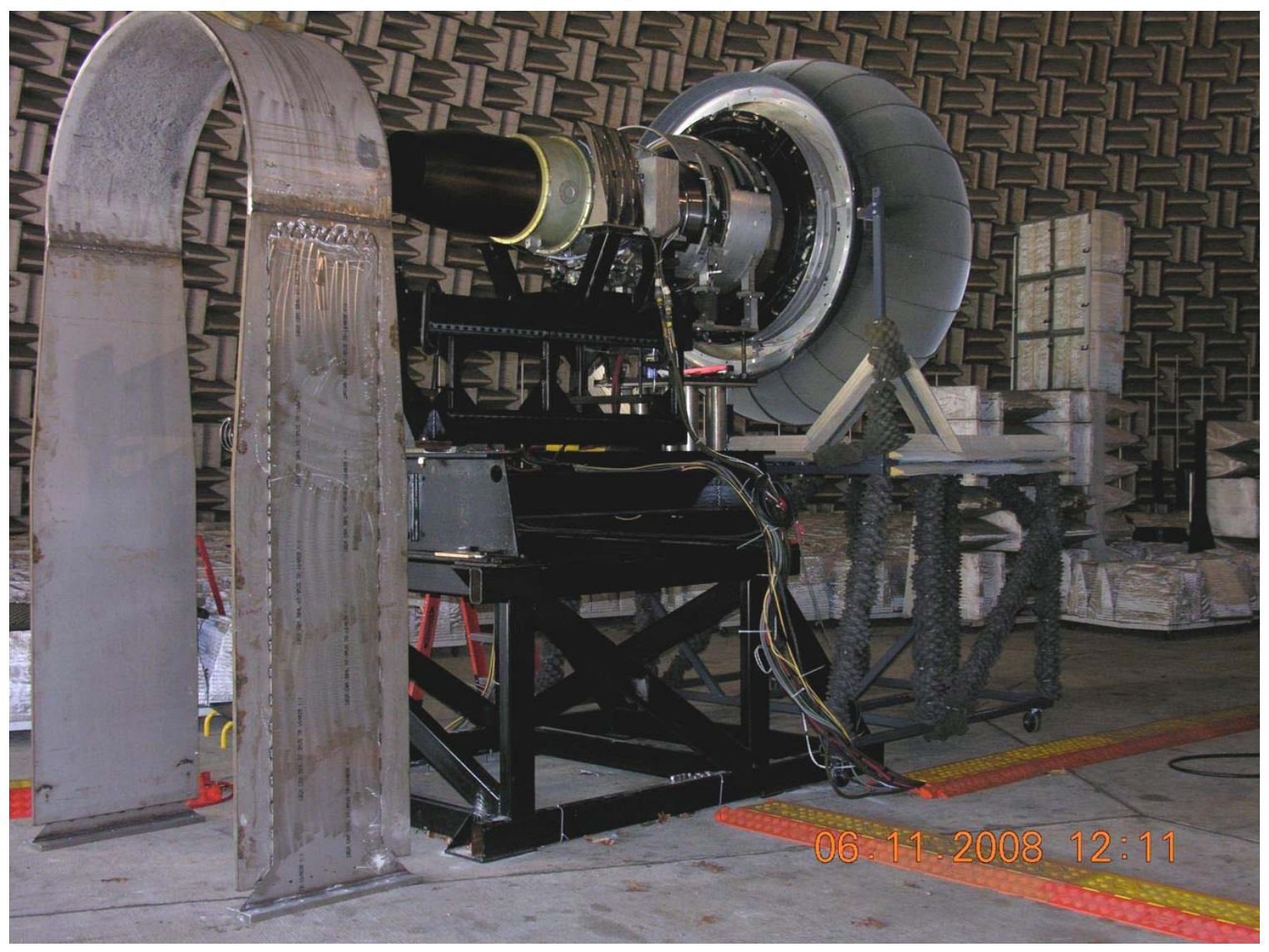

Figure 7.-Schematic test stand and containment shield. 


\section{Measurements}

\section{Farfield}

The primary metric for determining the efficacy of acoustic treatment is farfield acoustics. An overhead microphone array was used to acquire the farfield acoustic data (Fig. 5). This array is nominally centered about the AAPL center. Because the FJ44 was off-center of the AAPL, this array was not in a plane with the engine and therefore individual microphones are at different azimuthal angles. Table II provides the locations of the overhead array microphones relative to the engine inlet lip and centerline reference.

The overhead acoustic array consisted of 28 Bruel \& Kjaer (B\&K) model 4939 microphones. These 1/4-in. free-field microphones have a nominal sensitivity of $4 \mathrm{mV} / \mathrm{Pa}$, a frequency range of $4 \mathrm{~Hz}$ to $100 \mathrm{KHz}$, and a dynamic range of 28 to $164 \mathrm{~dB}$. B\&K model 2670 1/4-in. preamplifiers were used. These are connected to 7 Nexus Model 26904 -channel signal-conditioning amplifiers. The conditioned signals are fixed-rate sampled and stored on an R.C. Electronics Datamax II data acquisition unit. The Datamax has integral anti-aliasing filters.

To obtain a representation of the fuselage impingement noise, an additional array was located on a constant $10 \mathrm{ft}$ arc from the engine lip. This array was at the 10-ft-high standard and aligned with the engine centerline in the horizontal plane of the engine as shown in Figure 6. Table III provides the locations of the array microphones relative to the engine inlet lip. This near-field array used 15 PCB Piezotronics 130D20 microphones with integral preamplifiers. The signals are routed to a PCB model 481A signal conditioner. These microphones have a bandwidth of 100 to $4000 \mathrm{~Hz}( \pm 1 \mathrm{~dB})$; or 20 to $15000 \mathrm{~Hz}$ ( -2 to $5 \mathrm{~dB}$ ), with a nominal sensitivity of $45 \mathrm{mV} / \mathrm{Pa}$ at $1 \mathrm{kHz}$. The outputs of the signal conditioner were anti-aliased using Signal Processing Solutions (SPS) digital filters. The filtered signals were synchronously sampled and recorded on a Nicolet Odyssey 16-channel data acquisition computer.

Figure 7 shows the coordinate systems used in AAPL.

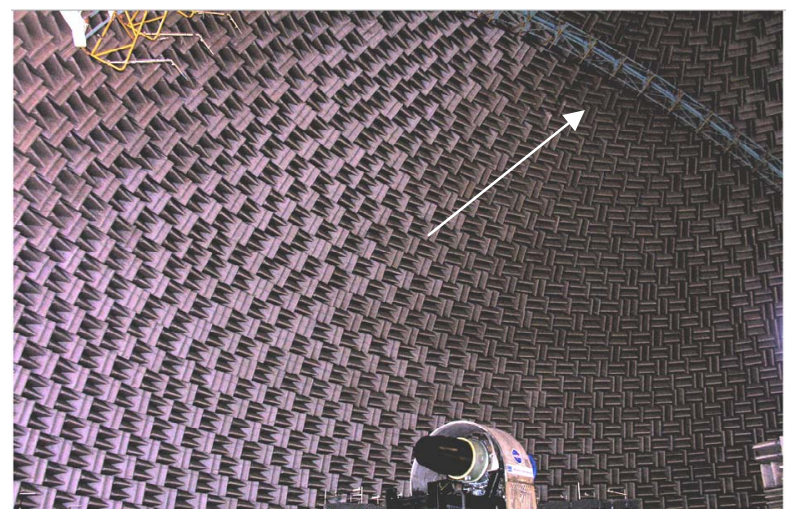

Figure 5.-Standard AAPL overhead array.

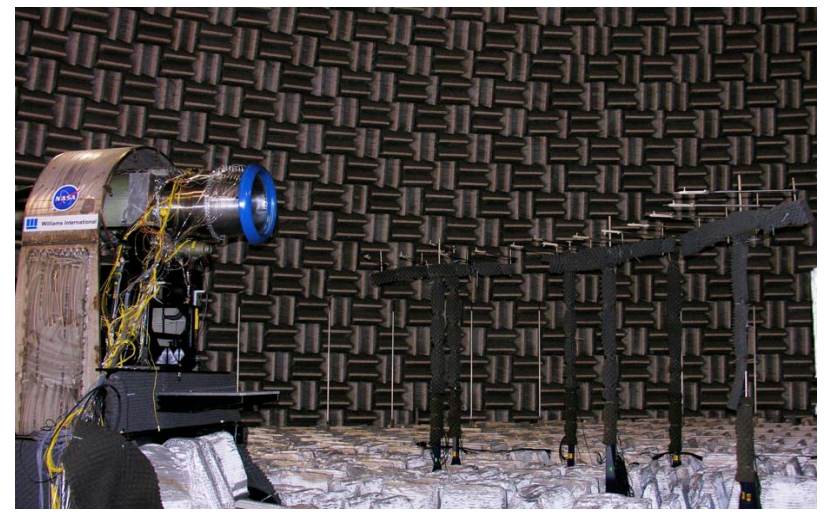

Figure 6.-Custom $10 \mathrm{ft}$ arc array.

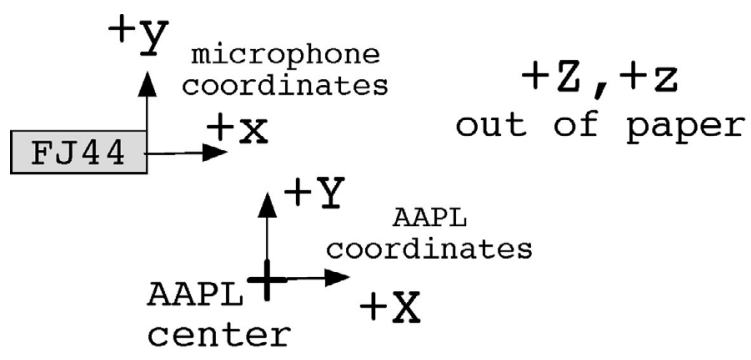

Figure 7.-Coordinate systems. 
TABLE II.-OVERHEAD ARRAY MICROPHONE LOCATIONS ARC TO INLET LIP

\begin{tabular}{|c|c|c|c|c|}
\hline Mic \# & $\mathrm{z},(\mathrm{ft})$ & $\mathrm{y}(\mathrm{ft})$ & $\mathrm{x}(\mathrm{ft})$ & Serial \# \\
\hline 21 & 56.74 & -13.10 & -16.92 & 2190087 \\
\hline 22 & 56.61 & -17.02 & -17.04 & 2520593 \\
\hline 23 & 56.03 & -20.94 & -16.96 & 2356103 \\
\hline 24 & 55.11 & -24.85 & -16.26 & 2226021 \\
\hline 25 & 51.21 & -31.40 & -13.29 & 2356110 \\
\hline 26 & 51.69 & -28.77 & -15.31 & 2520596 \\
\hline 27 & 48.61 & -33.60 & -11.30 & 2327874 \\
\hline 28 & 45.79 & -35.55 & -9.24 & 2520634 \\
\hline 29 & 42.78 & -37.04 & -7.30 & 2327872 \\
\hline 30 & 39.61 & -38.58 & -5.43 & 2520602 \\
\hline 31 & 36.08 & -39.56 & -3.65 & 2190037 \\
\hline 32 & 32.64 & -40.50 & -1.96 & 2356051 \\
\hline 33 & 29.11 & -40.75 & -0.41 & 2520631 \\
\hline 34 & 25.47 & -41.02 & 1.04 & 2520597 \\
\hline 35 & 21.62 & -40.89 & 2.34 & 2356107 \\
\hline 36 & 17.87 & -40.42 & 3.45 & 2356101 \\
\hline 37 & 14.16 & -39.64 & 4.51 & 2151632 \\
\hline 38 & 10.45 & -38.67 & 5.35 & 2520595 \\
\hline 39 & 6.86 & -37.20 & 6.02 & 2356106 \\
\hline 40 & 3.35 & -35.54 & 6.52 & 2327876 \\
\hline 41 & 0.00 & -33.63 & 6.84 & 2356053 \\
\hline 42 & -3.21 & -31.48 & 7.01 & 2356045 \\
\hline 43 & -6.43 & -29.08 & 6.93 & 2520600 \\
\hline 44 & -9.22 & -26.37 & 6.70 & 2546481 \\
\hline 45 & -11.98 & -23.63 & 6.30 & 2520605 \\
\hline 46 & -14.33 & -20.57 & 5.72 & 2356111 \\
\hline 47 & -16.66 & -17.48 & 4.97 & 2356097 \\
\hline 48 & -18.72 & -14.29 & 4.04 & 2254672 \\
\hline
\end{tabular}

TABLE III-—10 FT. ARRAY MICROPHONE LOCATIONS ARC TO INLET LIP

\begin{tabular}{|c|c|c|c|c|c|}
\hline Mic \# & $\mathrm{x}(\mathrm{ft})$ & $\mathrm{y}(\mathrm{ft})$ & $\mathrm{r}(\mathrm{ft})$ & $\theta$ & Serial \# \\
\hline 1 & 10.00 & 0.00 & 10.00 & 0 & 16950 \\
\hline 2 & 9.90 & 1.39 & 10.00 & 8 & 17391 \\
\hline 3 & 9.61 & 2.76 & 10.00 & 16 & 17389 \\
\hline 4 & 9.14 & 4.07 & 10.01 & 24 & 17390 \\
\hline 5 & 8.48 & 5.30 & 10.00 & 32 & 17386 \\
\hline 6 & 7.66 & 6.43 & 10.00 & 40 & 17342 \\
\hline 7 & 6.69 & 7.43 & 10.00 & 48 & 17387 \\
\hline 8 & 5.59 & 8.29 & 10.00 & 56 & 16956 \\
\hline 9 & 4.38 & 8.99 & 10.00 & 64 & 16954 \\
\hline 10 & 3.09 & 9.51 & 10.00 & 72 & 16955 \\
\hline 11 & 1.74 & 9.85 & 10.00 & 80 & 17393 \\
\hline 12 & 0.35 & 9.99 & 10.00 & 88 & 16951 \\
\hline 13 & 2.00 & 10.00 & 10.20 & 11.3 & 16957 \\
\hline 14 & 6.00 & 10.00 & 11.66 & 31.0 & 16953 \\
\hline 15 & 10.00 & 10.00 & 14.14 & 45.0 & 17340 \\
\hline
\end{tabular}

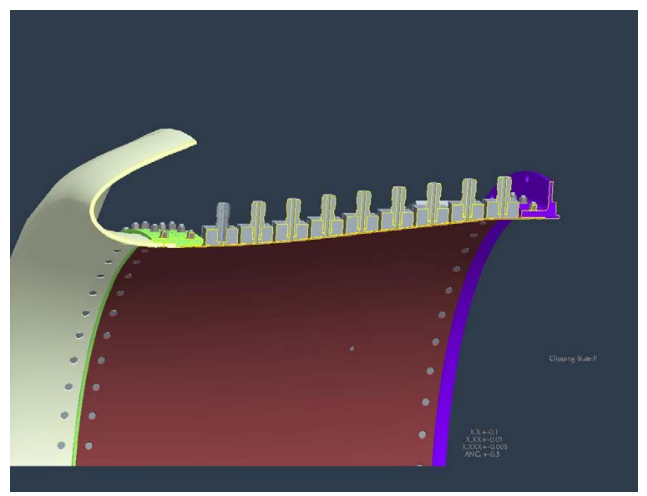

Figure 8.-Dynamic pressure instrumentation.

\section{Dynamic Pressures}

An axial array of high-response transducers measured the unsteady pressure along the inlet duct wall (Fig. 8). The inner wall dynamic pressure system used 9 Kulite model XCS-133-093 pressure transducers connected to Endevco Bridge Transducer Model 4430A signal conditioners. The outputs of the signal conditioners were synchronously sampled and recorded on a 32-channel Nicolet Odyssey data acquisition unit. An external SPS 32-channel digital filter was used for anti-aliasing. The locations of the transducers are provided in Table IV. This data was used to measure the shock wave generated by the fan above sonic tip speeds. 


\section{Rotating Rake}

The Rotating Rake system (Ref. 5) is a continuously rotating radial microphone rake that was inserted into the inlet duct, providing a complete map of the acoustic duct modes present in the engine. The rake is synchronized to the fan shaft speed at a 1/400 ratio. It has 14-embedded, radially-distributed, Endevco model 8507C-5 PSIG pressure transducers. These were connected to Endevco Bridge Transducer Model 4430A signal conditioners. Table V lists the locations of the transducers. The signals are then anti-alias filtered by the SPS digital filters, digitized and recorded on a 32-channel Nicolet Odyssey system.

Figure 9 shows the rake assembly and drive motor integrated with the FJ44. Figure 10 shows close-ups of the rake. Note that the ICD is still required for flow conditioning while acquiring rotating rake data. A low light level camera was mounted in the center of the ICD to monitor the rotating rake during operation.

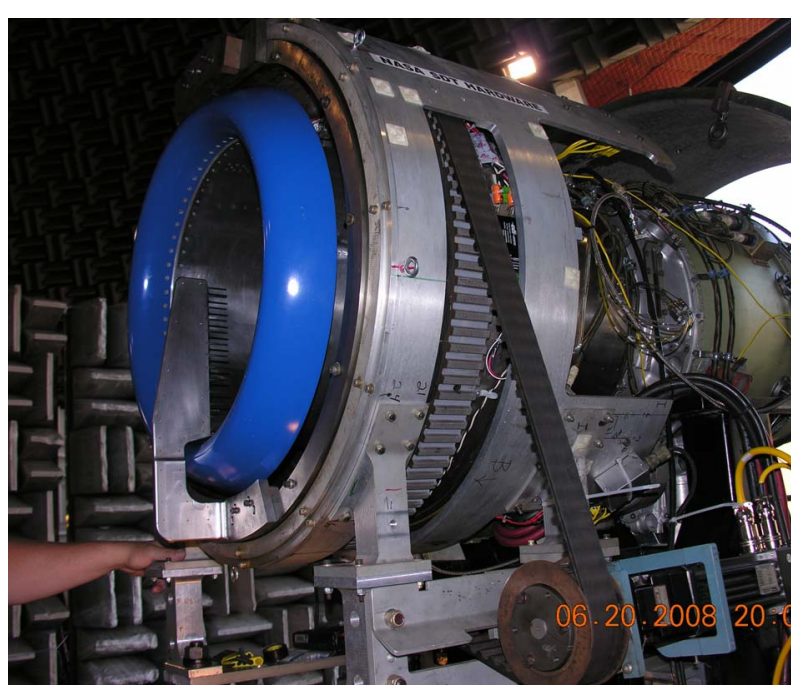

Figure 9.--Rotating rake assembly installed on engine.

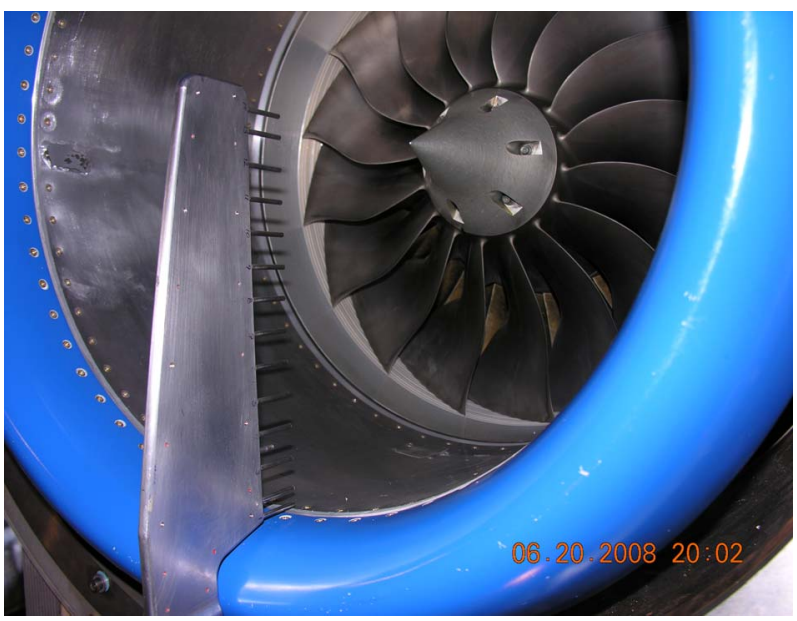

Figure 10.-Close-up of rotating rake. 
TABLE IV.-INNER WALL PRESSURE TRANSDUCERS

\begin{tabular}{|c|c|c|}
\hline Mic \# & $\begin{array}{c}\text { Axial } \\
\text { position, } \\
\text { in. }{ }^{\text {a }}\end{array}$ & Serial \# \\
\hline 1 & 10.5625 & $6726-2-379$ \\
\hline 2 & 9.5000 & $7273-7-450$ \\
\hline 3 & 8.3750 & $6726-2-382$ \\
\hline 4 & 7.3125 & $6726-7-376$ \\
\hline 5 & 6.2500 & $6726-2-378$ \\
\hline 6 & 5.1250 & $6726-2-373$ \\
\hline 7 & 4.0625 & $7273-7-447$ \\
\hline 8 & 3.0000 & $7273-7-435$ \\
\hline 9 & 1.9375 & $7273-7-451$ \\
\hline \multicolumn{2}{|c|}{ Measured from inlet/shroud flange junction. } \\
\hline
\end{tabular}

TABLE V.-ROTATING RAKE PRESSURE TRANSDUCERS

\begin{tabular}{|c|c|c|c|}
\hline Mic \# & $\begin{array}{c}\text { Radial } \\
\text { position \#1, } \\
\text { in. }\end{array}$ & $\begin{array}{c}\text { Radial } \\
\text { position \#2, } \\
\text { in. }\end{array}$ & Serial \# \\
\hline 1 & 0.1875 & 0.3750 & 10737 \\
\hline 2 & 0.5625 & 0.7500 & 10746 \\
\hline 3 & 1.3125 & 1.5000 & 10747 \\
\hline 4 & 2.1250 & 2.3125 & 10798 \\
\hline 5 & 2.8750 & 3.0625 & 10800 \\
\hline 6 & 3.6250 & 3.8125 & 10802 \\
\hline 7 & 4.3750 & 4.5625 & 10805 \\
\hline 8 & 5.1250 & 5.3125 & 10808 \\
\hline 9 & 5.8750 & 6.0000 & 10814 \\
\hline 10 & 6.6250 & 6.7500 & 10817 \\
\hline 11 & 7.3750 & 7.5625 & 10823 \\
\hline 12 & 8.1250 & 8.3125 & 10828 \\
\hline 13 & 8.9375 & 9.0625 & 10829 \\
\hline 14 & 9.4375 & 9.5625 & 10832 \\
\hline
\end{tabular}

\section{Steady State Pressures}

Eight total pressure rakes (5 probes each) were mounted in the inlet duct (Fig. 11). Three total pressure and three total temperature rakes were mounted in the fan bypass duct. Steady state pressure data was obtained by using the facility's Electronically Scanned Pressure (ESP) system, Pressure Systems Incorporated (PSI) System 8400. This system is comprised of a central processing unit (System Processor), and rack mounted pressure scanner modules, which consist of 32 channels of pressure transducers per module. Two different pressure range modules (15- and 45-psi) were used. By using this setup, many pressure ports can be scanned at a high accuracy of \pm 0.05 percent of full scale. Overall control of this setup is performed by a standard PC, which in turn is networked with the facility steady state data acquisition system, or ESCORT (NASA's in-house central data system). The pressure data is displayed and recorded using ESCORT. All static pressure data was obtained using the 15-psi ESP modules. Fan inlet total pressures also used the 15-psi modules, whereas a 45-psi module was used for the fan bypass total pressures. Figure 12 shows a photo of the inlet rakes. The rakes were qualified by Williams International in an earlier program and were "ping" tested prior to usage in this program.

Other steady state measurements included the use of type K thermocouples to obtain total temperature data in the bypass duct. Ambient conditions (barometer, temperature, etc.) were also recorded using the facility's ESCORT steady state data acquisition system. Engine health parameters such as speed, temperature, and vibration were recorded. 


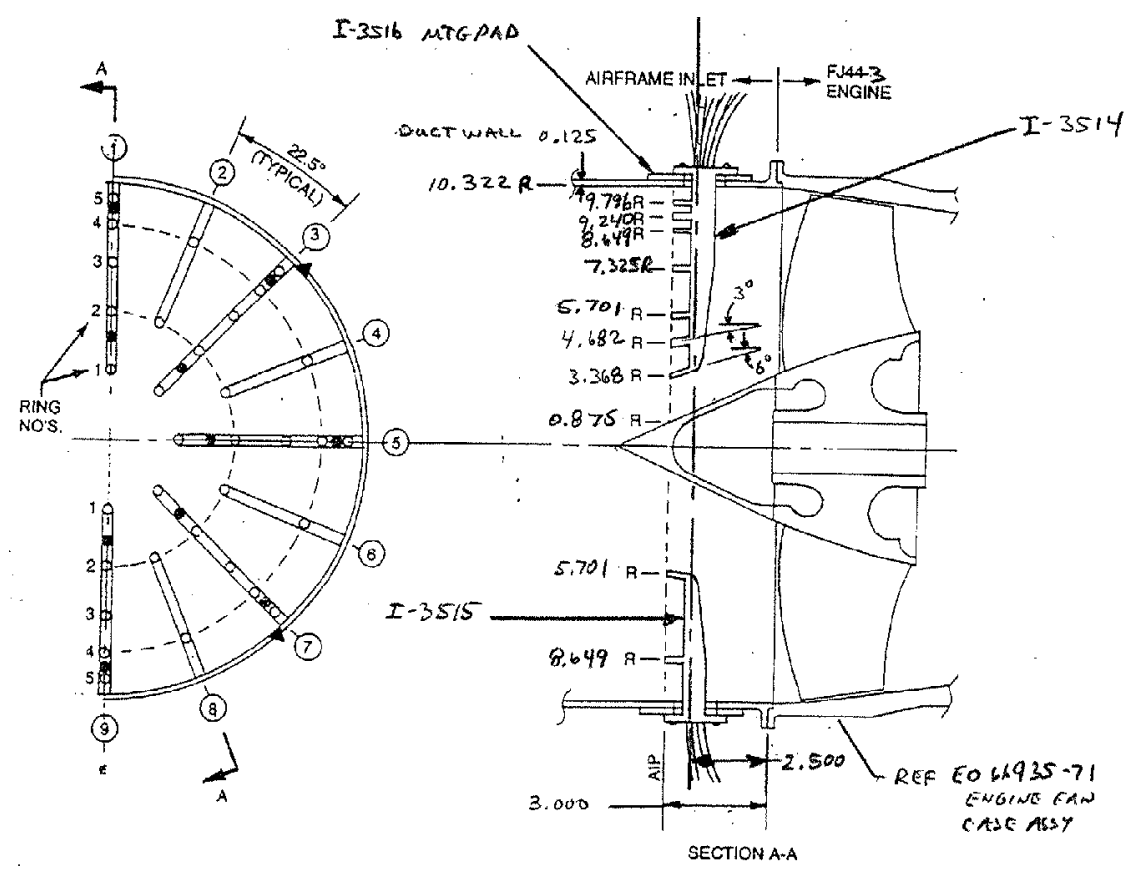

Figure 11.-Schematic of steady state pressure instrumentation.

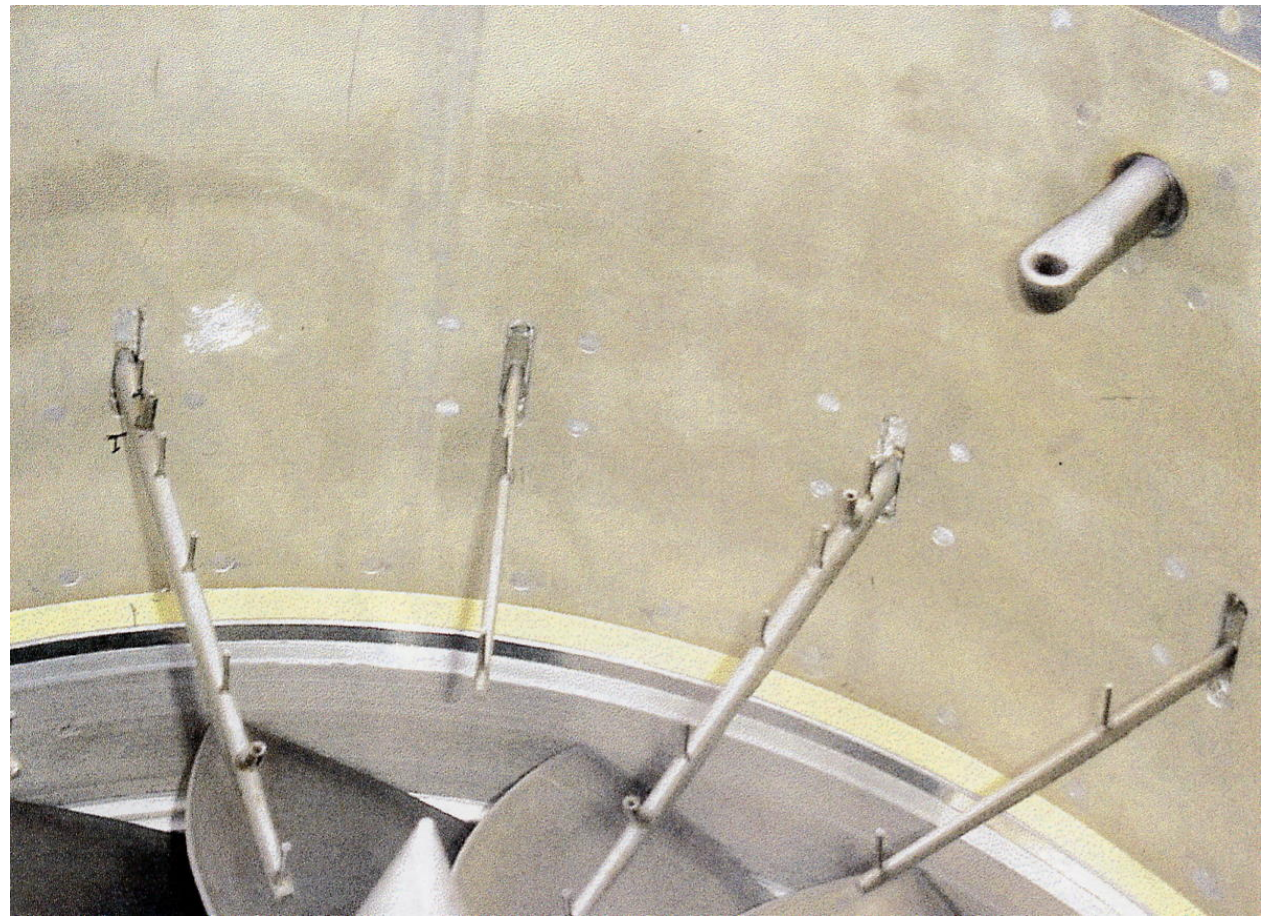

Figure 12.-Photo of steady state pressure instrumentation. 


\section{Test Matrix and Conditions}

Test conditions varied from ground idle (26\% N1-actual) to a max speed $(103 \% \mathrm{~N} 1 \mathrm{c})$ where N1 is the inlet fan rpm (Table VI). Data were acquired in a sweep starting at the max rpm and progressing to lower rpm. The over-head farfield data, the near-field acoustic data and inlet dynamic (when installed) were acquired during the same sweep (the near-field data and inlet data were actually acquired simultaneously). Rotating rake and performance data were each acquired in separate sweeps. All data sweeps for a given configuration were acquired in the same evening.

TABLE VI.-OVERALL TEST MATRIX

\begin{tabular}{|c|c|c|}
\hline CONFIG & DESCRIPTION & RUN CONDITIONS \\
\hline HW0 & $\begin{array}{l}\text { Hardwall configuration - Customer inlet, } \\
\text { temporary fan shroud/rotor components } \\
\text { (bent rotor blade tips } 4 \text { \& } 11 \text { exhibits } \\
\text { MPTs) }\end{array}$ & $\begin{array}{l}\text { Tested: } 3 \text { locations of Acoustic Phased Array data at } \\
26 \%, 59 \%, 65 \%, 71 \%, 76 \%, 82 \%, 88 \%, 94 \%, 100 \% \text {, } \\
103 \% \text { N1 RPM }\end{array}$ \\
\hline HW1 & $\begin{array}{l}\text { Hardwall configuration - New inlet \& } \\
\text { baseline fan shroud/rotor components } \\
\text { (same as last fall) }\end{array}$ & $\begin{array}{l}\text { Tested: Performance rake data (pressure and } \\
\text { temperature) as well as static wall pressures and } \\
\text { Acoustics (Far-field as well as in-duct Kulite data) at } \\
26 \%, 59 \%, 71 \%, 76 \%, 88 \%, 100 \%, 103 \% \text { N1 RPM }\end{array}$ \\
\hline HW2 & $\begin{array}{l}\text { Hardwall configuration - New inlet \& new } \\
\text { non-perforated fan shroud component }\end{array}$ & $\begin{array}{l}\text { Tested: Performance rake data (pressure and } \\
\text { temperature) as well as static wall pressures and } \\
\text { Acoustics (Far-field, in-duct Kulite data as well as } \\
\text { Rotating Rake data) at } 26 \%, 59 \%, 65 \%, 71 \%, 76 \% \text {, } \\
82 \%, 88 \%, 94 \%, 100 \% \mathrm{~N} 1 \mathrm{RPM}\end{array}$ \\
\hline A1-80 & Fan case only treated - 80 ppi foam & $\begin{array}{l}\text { Tested: Performance rake data (pressure and } \\
\text { temperature) as well as static wall pressures and } \\
\text { Acoustics (Far-field as well as in-duct Kulite data) at } \\
26 \%, 59 \%, 65 \%, 71 \%, 76 \%, 82 \%, 88 \%, 94 \%, 100 \% \\
\text { N1 RPM }\end{array}$ \\
\hline A1t- 80 & $\begin{array}{l}\text { Fan case only treated - } 80 \text { ppi foam (over } \\
\text { the rotor only) }\end{array}$ & $\begin{array}{l}\text { Tested: Performance rake data (pressure and } \\
\text { temperature) as well as static wall pressures and } \\
\text { Acoustics (Far-field as well as in-duct Kulite data) at } \\
26 \%, 59 \%, 65 \%, 71 \%, 76 \%, 82 \%, 88 \%, 94 \%, 100 \% \\
\text { N1 RPM }\end{array}$ \\
\hline A2-40 & Fan case only treated - 40 ppi foam & $\begin{array}{l}\text { Tested: Performance rake data (pressure and } \\
\text { temperature) as well as static wall pressures and } \\
\text { Acoustics (Far-field, in-duct Kulite data) at } 26 \%, 59 \% \text {, } \\
65 \%, 71 \%, 76 \%, 82 \%, 88 \%, 94 \%, 100 \% \text { N1 RPM }\end{array}$ \\
\hline SDOF-71 & $\begin{array}{l}\text { Inlet only treated w/ new non-perforated } \\
\text { fan shroud component - C-71 - Hybrid } \\
\text { thick/thin treatment zones }\end{array}$ & $\begin{array}{l}\text { Tested: Acoustics (Far-field as well as in-duct Kulite } \\
\text { data) at } 26 \%, 59 \%, 65 \%, 71 \%, 76 \%, 82 \%, 88 \%, 94 \% \text {, } \\
100 \% \text { N1 RPM }\end{array}$ \\
\hline SDOF-72 & $\begin{array}{l}\text { Inlet only treated w/ new non-perforated } \\
\text { fan shroud component - C- } 72 \text { - Thin core } \\
\text { treatment }\end{array}$ & $\begin{array}{l}\text { Tested: Acoustics (Far-field as well as in-duct Kulite } \\
\text { data) at } 26 \%, 59 \%, 65 \%, 71 \%, 76 \%, 82 \%, 88 \%, 94 \% \text {, } \\
100 \% \text { N1 RPM }\end{array}$ \\
\hline
\end{tabular}




\section{Conclusions}

The Williams International FJ44-3A turbofan engine was successfully and safely tested in the AeroAcoustic Propulsion Laboratory. Support and safety structures were incorporated into the AAPL facility in order to run a full-scale engine in a component test facility. An overview of the installation and operation of the engine in the AAPL facility was documented. This paper will serve as a reference for the papers reporting the acoustic and limited performance results from these configurations.

\section{References}

1. Huff, D.L., "Noise Reduction Technologies for Turbofan Engines," Proceedings of Inter-Noise 2006, IN06 732, December 2006.

2. Sutliff, D.L. and Jones, M.G., "Foam-Metal Liner Attenuation of Low-Speed Fan Noise," AIAA2008-2897, also NASA/TM-2006-214368

3. Cooper, B.A., "A Large Hemi-Anechoic Chamber Enclosure for Community-Compatible Aeroacoustic Testing of Aircraft Propulsion Systems," Journal of the Institute of Noise Control Engineering of the USA, Jan/Feb 1994.

4. Buckley, J.L., "Containment Shield Design for Williams International FJ44-3 Engine in AeroAcoustic Propulsion Laboratory at NASA Glenn," ASRC Task \# NNC08E271T.

5. Sutliff, D.L., "Rotating Rake Mode Measurement System,” NASA/TM-2005-213828. 


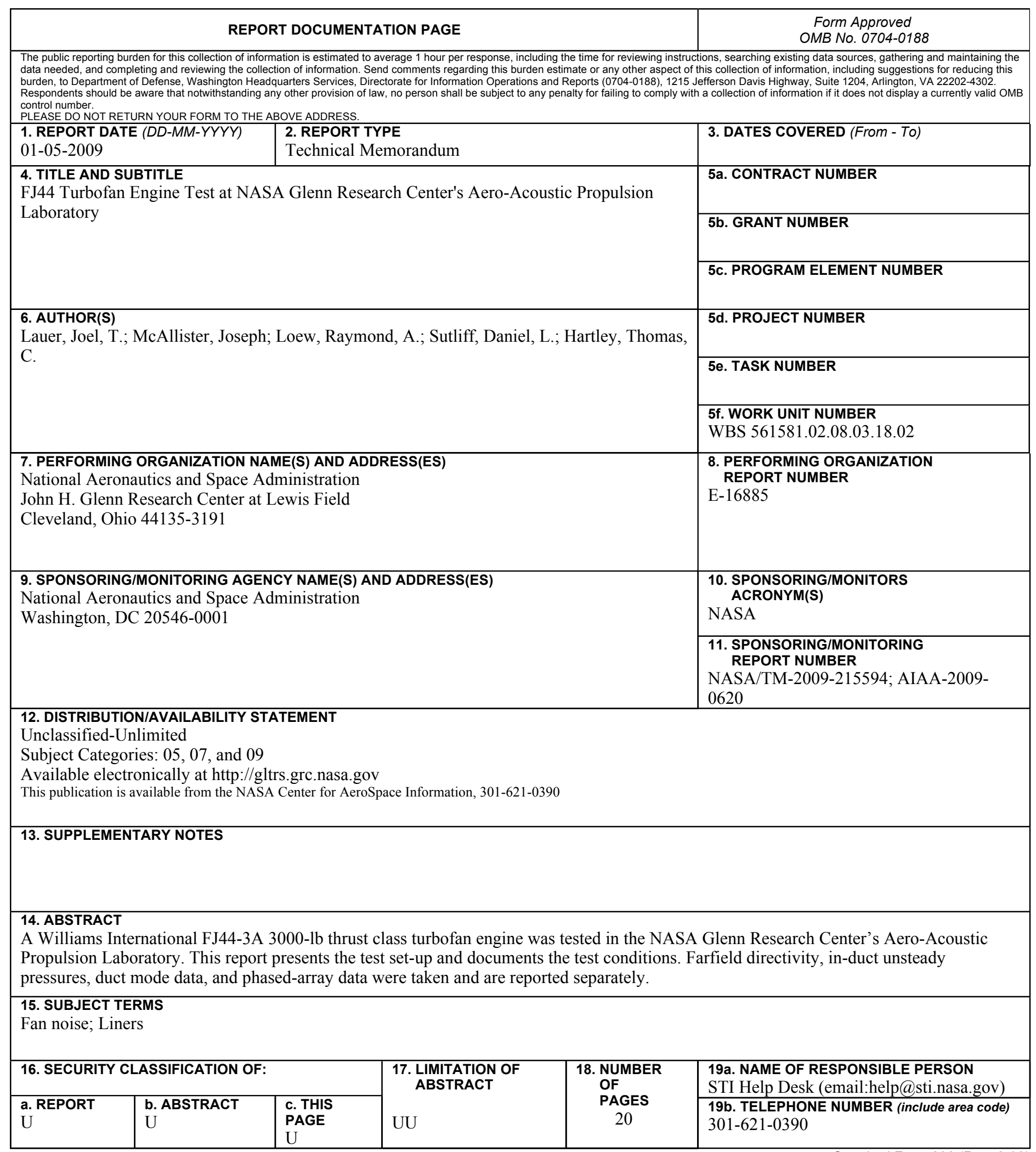



